\title{
MODELING MICROBIAL WATER QUALITY AT A BEACH IMPACTED BY MULTIPLE NON- POINT SOURCES
}

\author{
Zhixuan Feng ${ }^{1}$, Ad Reniers ${ }^{1}$, Brian Haus ${ }^{1}$, Helena Solo-Gabriele ${ }^{2}$, Laura Fiorentino ${ }^{1}$, Maria Olascoaga ${ }^{1}$ and Jamie \\ MacMahan $^{3}$
}

\begin{abstract}
Monitoring microbial water quality is essential for recreational beaches in order to protect human health. To evaluate the relative importance and impacts of various types of non-point microbial sources at a subtropical beach (Hobie Beach, Miami, USA), we utilized a coastal ocean circulation model (Delft3D) with a microbe transport-fate model. Those non-point sources include beach sediment, dog feces, bather shedding, and rainfall runoff. The hydrodynamic model results agreed well with tidal elevations recorded by a nearby NOAA tidal station and also field data collected by pressure sensors, acoustic Doppler current profiler (ADCP). We modeled enterococci levels from four different types of non-point sources on the beach and Staphylococcus aureus levels from only the bather shedding. Model results suggest that dog feces are spotty sources of enterococci and can result in transient spikes of enterococci levels for hours. Beach sands are pervasive sources of enterococci and may explain observed persistent elevations of enterococci levels at this site. Runoff may also significantly increase enterococci levels during rainfall events while bather shedding contribution of enterococci is almost negligible. Bather is the only Staphylococcus aureus source considered in the study and simulated levels are in the same order as prior field measurements.
\end{abstract}

Keywords: water quality; recreational beach; enterococci; Staphylococcus aureus; non-point source; Delft3D

\section{Introduction}

Coastal waters have been extensively used as recreational resources, such as swimming, boating, and fishing. At the same time, microbial water quality is becoming a concern since certain microorganisms may cause diseases and pose potential risks to human health. Globally, it has been estimated that a total of 120 million cases of gastrointestinal diseases and 50 million cases of respiratory diseases occur annually in relation to bathing/swimming in impaired marine waters (Shuval, 2003). The US Environmental Protection Agency (USEPA) set up guidelines and recommended enterococci as an indicator microbe for marine water (USEPA, 1986). To be considered "safe", the enterococci level of single seawater sample should be less than 104 colony forming unit (CFU) or most probable number (MPN) per $100 \mathrm{~mL}$, or $35 \mathrm{CFU} / 100 \mathrm{ml}$ of geometric mean. Otherwise, beach advisories or even closures will be issued by local beach managers. Traditional culture-based methods require about a day for lab analysis and exceedance of fecal indicator bacteria cannot be identified until the second day. Model approaches can play important roles in beach management, supplementing existing beach monitoring programs.

Process models have been widely applied to identify fecal pollutant sources, track their pathways, retentions, and fates in the water column, and evaluate the impacts of various processes. Deterministic modeling of microbe levels requires comprehensive understanding of physical, chemical and biological processes and their interactions and also abundant data sets for model calibration, parameterization, validation and verification. For example, Sander et al. (2005) found that urban runoff and resuspended wetland sediment are two factors controlling fecal indicator bacteria at a California marsh from a 2D depth-integrated model experiment. Liu et al. (2006) suggested that tributaries were major fecal pollutant sources by studying different processes affecting water quality of Lake Michigan beaches. Zhu et al. (2011) evaluated three non-point bacteria loads, bather shedding, dog feces and beach sand, to a south Florida beach and identified that a dog fecal event can elevate enterococci levels above the limit for several hours.

In this study, we utilized a hydrodynamic model, Delft3D-FLOW, to simulate transport and fate of two types of bacteria of interest (i.e., enterococci and Staphylococcus aureus), in order to evaluate and compare the impacts of multiple non-point sources existing on a beach under ideal scenarios. While enterococcus is a widely used fecal indictor, S. aureus, common human colonizing bacteria, can be shed from bathers and may potentially cause skin infections in recreational marine waters (Plano et al., 2011).

\footnotetext{
${ }^{1}$ Rosenstiel School of Marine and Atmospheric Science, University of Miami, Miami, FL 33149, USA

2 Department of Civil, Architectural\& Environmental Engineering, University of Miami, Coral Gables, FL 33124, USA

${ }^{3}$ Department of Oceanography, Naval Postgraduate School, Monterey, CA 93943, USA
} 


\section{Materials and Methods}

\subsection{Site description}

Hobie Beach is a subtropical marine beach located in the Virginia Key of Biscayne Bay, to the east of the city of Miami, Florida, United States of America (Figure 1). The beach has a length of 1,600 m, and an orientation of northwest-southeast. Because of its location inside a coastal embayment, Biscayne Bay, the beach is protected from strong wave ifluence. Local tide is dominated by the principal lunar semidiurnal constituent (M2) and has a tidal range of approximately $0.6 \mathrm{~m}$. The currents nearshore the beach are weak, although become much stronger in an adjacent tidal inlet, Bear Cut (Zhu et al., 2011). This beach is characterized by frequently elevated indictor microbes and high percentage of exceedance although no known point source of fecal pollution could be identified (Shibata, et al. 2004). Hobie Beach is the only beach in Miami-Dade County that allows visitors to bring their pets. Potential nonpoint sources of bacteria were found by prior field studies: sand (Shibata et al., 2004; Wright et al., 2011; Shah et al., 2011), animals, particularly dog (Wright et al., 2009), human (Elmir et al., 2007 \& 2009), and rainfall runoff (Wright et al., 2011).

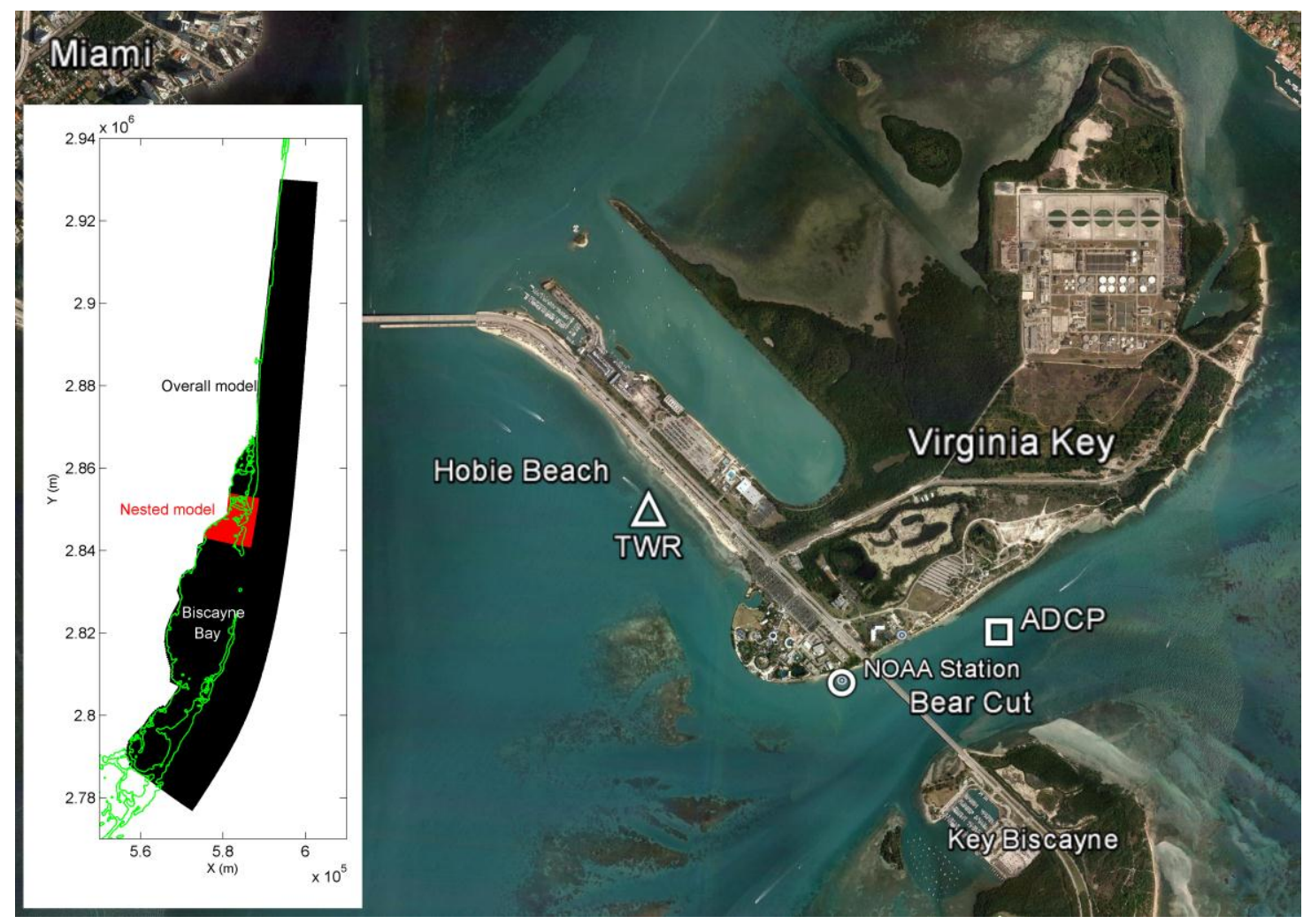

Figure 1 Hobie Beach and computational mesh. NOAA Virginia Key Station is shown with a white cycle. ADCP is illustrated with the white square. Tide and Wave Recorder (TWR) is indicated by the white triangle. Left window shows the computational grid for overall model (black lines), and nested model (red lines). Coastline is shown with green lines.

\subsection{Model Setup and Implementation}

\subsubsection{Hydrodynamic model}

Delft3D-FLOW employs implicit finite difference schemes to numerically solve shallow water equation in either two (2DH, depth-averaged) or three dimensions (3D) (Lesser et al., 2004). A one-way offline nesting technique was applied in this study in order to refine grid resolution around Hobie Beach where microbial contaminants originated from the beach may have significant impacts. The overall model domain is horn-shaped with a length of about $150 \mathrm{~km}$ and widths of 16-29 km (Figure 1). It contains entire Biscayne Bay and a narrow strip of continental shelf, allowing tidal waves propagating along the shelf and into the bay. The domain of nested model centered at Virginia Key and has a grid resolution of approximately $30 \mathrm{~m}$. The depth for model input was constructed from two data sources. Inside the bay, $30 \mathrm{~m}$ resolution U.S. estuarine bathymetry data for Biscayne Bay was utilized. The shelf 
depths were triangle-interpolated from National Geophysical Data Center (GEODAS) 3 arc second $(\sim 90 \mathrm{~m})$ bathymetry. The simulations neglected either salinity or temperature variations based on the following considerations: (1) no major river discharges into the Biscayne Bay so that salinity-driven baroclinic gradient is relatively small, and (2) the bay is so shallow $(<4 \mathrm{~m})$ that thermal stratification is insignificant.

The overall model has three open boundaries: north, south, and seaward boundaries (Figure 1). The northern flow boundary was prescribed as water level boundary with astronomic tides (combinations of a total of 35 tidal constituents) obtained from NOAA's Lake Worth Pier station. The southern boundary is a Riemann radiation boundary, allowing southward propagating tidal waves to pass through freely. The seaward or western boundary is also a water level boundary, whose northmost and southmost points are harmonic water level at Lake Worth Pier and Virginia Key stations and all intermediate points are linearly interpolated from the above two. Since Virginia Key station is only nearby long-term tidal station that can be used for the southmost grid point but is still approximately $70 \mathrm{~km}$ away. To account for this issue, boundary corrections on amplitudes and phases of the largest five harmonic constituents (i.e., M2, S2, N2, K1, and O1) were conducted according to previous modeling efforts (Wang et al., 2003; Zhu, 2011). We also specified spatially uniform but time varying wind conditions to the model, based on the facts that model domain is relatively small compared to meteorological scale and surface winds are statistically homogenous and coherent in south Florida (Peng et al., 1999). Hourly wind measurements were obtained from National Data Buoy Center (NDBC) Fowey Rocks station, which is located in the middle of model domain. Since anemometer at this station is $43.9 \mathrm{~m}$ above the sea surface, wind speed was converted to a standard $U_{10}(10 \mathrm{~m}$ height wind speed $)$ by multiplying a factor of 0.676 based on the logarithmic vertical profile (Hsu, 1988).

\subsubsection{Microbe transport-fate model}

The transport-fate of microbes is modeled by a depth-averaged advection-diffusion equation:

$$
\frac{\partial h c}{\partial t}+\frac{\partial h u c}{\partial x}+\frac{\partial h v c}{\partial y}-\frac{\partial}{\partial x}\left[D_{x x} h \frac{\partial c}{\partial x}\right]-\frac{\partial}{\partial y}\left[D_{y y} h \frac{\partial c}{\partial y}\right]=\sum S_{i}-h \sum k_{j} c
$$

where $\mathrm{h}$ is water depth (in $\mathrm{m}$ ), $\mathrm{c}$ is the concentration of microbes (in CFU/ $\mathrm{m}^{3}$, specifically enterococci and $S$. aureus in this paper), $\mathrm{u}$ and $\mathrm{v}$ are depth-averaged velocities (in $\mathrm{m} / \mathrm{s}$ ), $\mathrm{D}_{\mathrm{xx}}$ and $\mathrm{D}_{\mathrm{yy}}$ are the turbulent diffusion coefficients (in $\mathrm{m}^{2} / \mathrm{s}$ ), $\mathrm{S}_{\mathrm{i}}$ represents source influx of $i$ th microbial load (in CFU $/ \mathrm{m}^{2} / \mathrm{s}$ ) existing on the beach, for instance, dog feces, beach sediment, human shedding, and rainfall runoff. The last term on the right hand side of Eq. (1) represents total decay rate of microbes with $\mathrm{k}_{\mathrm{j}}$ as a decay coefficient (in $\mathrm{s}^{-1}$ ) for a particular process, such as solar inactivation, dark inactivation, or grazing mortality. In this study, we only considered the predominant solar inactivation effect. A constant solarrelated decay rate of enterococci $\left(\mathrm{k}_{\mathrm{e}}=2.09 \times 10^{-4} \mathrm{~s}^{-1}=18.1\right.$ day $\left.^{-1}\right)$ was determined from typical literature value of laboratory experiments (Sinton et al., 2002). The decay rate of $S$. aureus $\left(\mathrm{k}_{\mathrm{s}}=1.27 \times 10^{-4} \mathrm{~s}^{-1}=\right.$ $11.0 \mathrm{day}^{-1}$ ) was obtained from literature (Fujioka and Unutoa, 2006). The corresponding 90\% die-off time periods $\left(\mathrm{T}_{90}\right)$ for enterococci and $S$. aureus are 3.1 and 5.0 hours, respectively. It should be noted that we only model far-field water quality assuming microbes are evenly distributed into the entire volume of source grid. Therefore, the initial concentration value is not only dependent on the source itself (i.e., source concentration and discharge rate), but also on the grid size and depth.

\subsubsection{Quantification of source loads}

As a first attempt, we only took into account ideal "worst case" scenarios, in which maximum potential loads from four types of microbial sources were evaluated. The quantification of source loads as model input was conducted by compiling literatures of prior field experiments at this beach. The loading rate, period, total load, and characteristics of four types of non-point sources for numerical experiments are summarized in Table 1.

\subsubsection{Dog fecal load}

Hobie Beach is the only beach in Miami-Dade County that allows pets. Dogs were found to be the most important animal fecal sources of enterococci to this beach (Wright et al., 2009; Wang et al., 2010; Zhu et al., 2010). Considering an average of $5.6 \times 10^{9} \mathrm{CFU}$ enterococci per large dog fecal event (Wright et al., 2009), we assumed this total amount of enterococci from one dog feces was released in an hour with a constant loading rate. We also assumed that dogs do not shed S. aureus to the water and also no $S$. aureus exists in dog feces. 


\begin{tabular}{|c|c|c|c|c|c|c|}
\hline \multicolumn{7}{|c|}{ Table 1. A summary of source loading in the model } \\
\hline Source & $\begin{array}{c}\text { Enterococci } \\
\text { rate (CFU/s) }\end{array}$ & $\begin{array}{c}\text { Total load } \\
(\mathrm{CFU})\end{array}$ & $\begin{array}{c}\text { S. aureus } \\
\text { rate } \\
\text { (CFU/s) }\end{array}$ & $\begin{array}{c}\text { Total load } \\
(\mathrm{CFU})\end{array}$ & Period & Characteristics \\
\hline $\begin{array}{c}\text { Dog } \\
\text { feces }\end{array}$ & $1.55 \times 10^{6}$ & $5.60 \times 10^{9}$ & 0 & 0 & $\begin{array}{c}\text { One hour, } \\
\text { low tide }\end{array}$ & $\begin{array}{l}\text { One large dog feces released in one } \\
\text { grid point the middle of the beach }\end{array}$ \\
\hline Sand & $2.36 \times 10^{5}$ & $4.24 \times 10^{10}$ & 0 & 0 & $\begin{array}{c}\text { One hour, } \\
\text { high tide }\end{array}$ & $\begin{array}{l}\text { Whole shoreline sand source } \\
\text { represented by } 50 \text { grid points }\end{array}$ \\
\hline Runoff & $1.50 \times 10^{6}$ & $4.32 \times 10^{10}$ & 0 & 0 & $\begin{array}{c}\text { One hour, } \\
\text { low tide }\end{array}$ & $\begin{array}{l}\text { Discharged through } 8 \text { spaced } \\
\text { runnels }\end{array}$ \\
\hline Human & $3.82 \times 10^{3}$ & $1.10 \times 10^{9}$ & $4.24 \times 10^{4}$ & $1.22 \times 10^{10}$ & 8 hours & $\begin{array}{l}\text { Continuous release from } 10 \text { grid } \\
\text { points in the middle of the beach }\end{array}$ \\
\hline
\end{tabular}

\subsubsection{Sand enterococci load}

Sand is a pervasive source of fecal bacteria at Hobie Beach (Wright et al., 2009; Shah et al., 2011). We considered a line source of enterococci along beach shoreline under a scenario of consistent and vigorous wave breaking and sediment resuspension, which continuously released enterococci from top sediment layers. The total ENT load was estimated from $10 \mathrm{~m}$ wide and $1 \mathrm{~cm}$ thick sediment layer along the entire shoreline with a maximum level of $100 \mathrm{CFU} / \mathrm{g}$ dry sand (Wright et al., 2011; Feng et al., 2012) and was released continuously and constantly for one hour at high tide. Note that although sand loading rate at one grid point was only $1 / 7$ to $1 / 6$ of dog fecal loading rate, the total load of sand was one order of higher than that of dog feces because of the pervasive distribution of sand. In addition, we assumed no $S$. aureus in the sand.

\subsubsection{Rainfall-runoff loading}

Microbes from upper dry beach face may enter water column through surface runoff via runnels during rainfall events. We designed a scenario that eight spaced runnels distributed along the beach. The maximum loading rate was estimated from an average enterococci level of 15,000 CFU/100 $\mathrm{mL}$ in the runoff (Wright et al., 2011) and a $10 \mathrm{~mm} / \mathrm{h}$ rainfall rate during summer thunderstorms (Feng et al., 2012), by applying the rational formula similar to Elmir (2006) and Feng et al. (2012). Note that the runoff loading rate seemed very close to dog fecal loading rate, while runoff total load was almost equal to sand total load (Table 1). We assumed no S. aureus in the runoff. The runoff loading lasted for one hour at low tide.

\subsubsection{Human load}

Bathers may shed both fecal bacteria and skin pathogens directly to beach water or indirectly through contact of sand (Elmir et al., 2007 \& 2009). For our modeling study, human is a source of enterococci and more importantly only primary source of $S$. aureus in this study. Previous studies estimated $10^{5}$ to $10^{6} \mathrm{CFU}$ shed per person per 15-min bathing period (Plano et al., 2011) and found strong correlations between $S$. aureus levels and bather loads (Enns et al., 2012). We applied an estimated mean $6.1 \times 10^{6}$ CFU S. aureus (Elmir et al., 2007) and $5.5 \times 10^{5}$ CFU enterococci per person per 15 min exposure period (Elmir et al., 2007) to calculate respective loading rate from the bather, and also used a maximum density of 0.156 bather per meter shoreline at summer weekends (Wang et al., 2010). The bather loads were released from ten neighboring grid points for eight consecutive hours, typical busy beach time from 10:00 am (low tide) to 18:00 pm (high tide).

\subsection{Field experiments}

To validate model hydrodynamics, data from a NOAA tidal station and prior field experiments in the study area were utilized. NOAA Virginia Key station (see Figure 1) provides long-term water level observations for this area. We compared entire month of January 2010 records with the simulation and conducted harmonic analysis to compare predominant M2 constituents. The other time series of water level were measured by a bottom-mounted tide and wave recorder (RBR TWR-2050, Ottawa, ON, Canada) every 32 s from 1 to 11 June 2010, just 190 m offshore Hobie Beach (see Figure 1).

The flow simulations were validated using measurements by a Nortek ADCP (Aquadopp profile, Annapolis, MD, USA) deployed in the nearby Bear Cut (See Figure 1). This was part of the fieldwork conducted for the first Naval Postgraduate School - University of Miami joint course (MacMahan et al., 2012). The ADCP was attached to a floating catamaran and deployed in the inlet channel to measure the velocity profile. It sampled at $1 \mathrm{~Hz}$ frequency from 10:18 to 17:05 (GMT), 19 January 2011. A total of 20 bins were preset and each bin represented a depth layer of $0.5 \mathrm{~m}$. However, only the first 10 bins were valid measurements because the channel is no deeper than $6.0 \mathrm{~m}$. Also, to eliminate 
internal noises associated with the ADCP, both north and east components were averaged every 6 minutes. Then, 6-min-averaged velocities were clockwise rotated $62^{\circ}$ to obtain along-channel and cross-channel components.

\section{Results}

\subsection{Observations and model validations}

\subsubsection{Tides}

We first validated the simulated tides at Virginia Key station for entire month of January 2011 and at Hobie Beach from 1 to 11 June 2010 (Figure 2). Modeled tidal elevations correlated well with observation during those two periods $(\mathrm{R}=0.96)$. Slight mismatches between model and observation are likely due to non-tidal processes, such as atmospheric pressure disturbance, and wind-induced coastal setup and setdown. We further applied T-Tides harmonic analysis (Pawlowicz et al., 2002) on the month-long time series. The amplitude and phase differences of dominant semidiurnal M2 tide between model and observation were within $0.02 \mathrm{~m}$ and $5^{\circ}$ (i.e. 10 minutes). Overall, the flow model yielded satisfactory water level hindcasts in the study area.
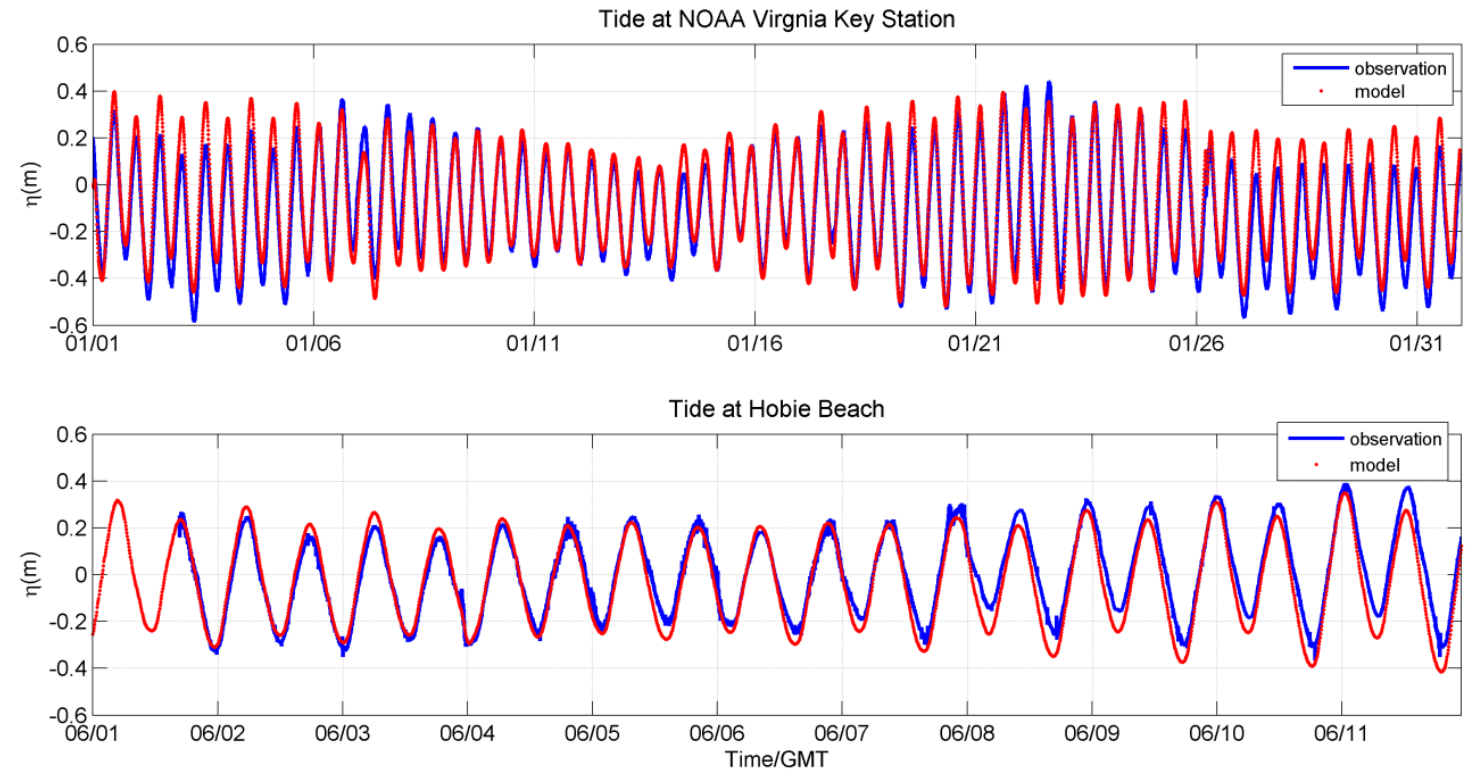

Figure 2 Model-observation comparisons of tides at NOAA Virginia Key station in January 2011 (upper panel) and at Hobie Beach 1 to 11 June 2010 (lower panel).

\subsubsection{Current}

The Eularian measurements of current at Bear Cut inlet were shown in Figure 3-A and -B and compared with model simulations at corresponding grid point (Figure 3-C). The ADCP measured for a period of nearly seven hours, covering half tidal cycle from mid flood tide to mid ebb tide. Tidal currents in the inlet channel were dominated by along-channel velocity component, the amplitude of which was much larger than cross-shore counterpart. The water column was well-mixed from surface to $3.5 \mathrm{~m}$ below and near-bottom velocity was significantly reduced due to the friction. One interesting and important feature observed by the ADCP was the flow asymmetry, showing that ebb flows were not in the exact opposite direction of flood flows but instead rotated clockwise (Figure 3-C). The crosschannel velocity contour illustrated persistent negative values (pointing to the opposite direction of northern channel bank) throughout the survey (Figure 3-B). In general, the model-predicted flows in the inlet channel agreed well with the ADCP measurements (Figure 3-C). Both model and observation showed that flood current velocities were near the maximum during the initial two hours, with magnitudes larger than $0.7 \mathrm{~m} / \mathrm{s}$. The flood flow gradually slowed down and reached to the minimum $(\sim 0.03 \mathrm{~m} / \mathrm{s})$ four hours after deployment. The occurrence of slack flow in the inlet channel lagged the highest local tide (observed at 13:00 GMT) at the Virginia Key station by 75 minutes, which indicated that tidal elevation and current were not exactly $90^{\circ}$ out of phase. The major difference between model and observation was the angle mismatch. Model-simulated currents were almost oriented in the channel 
direction, while ADCP-measured flood currents were about $20^{\circ}$ counterclockwise rotated and ebb currents were $10^{\circ}$ clockwise rotated to the inlet direction. Nevertheless, model hindcast yielded satisfactory current simulations.
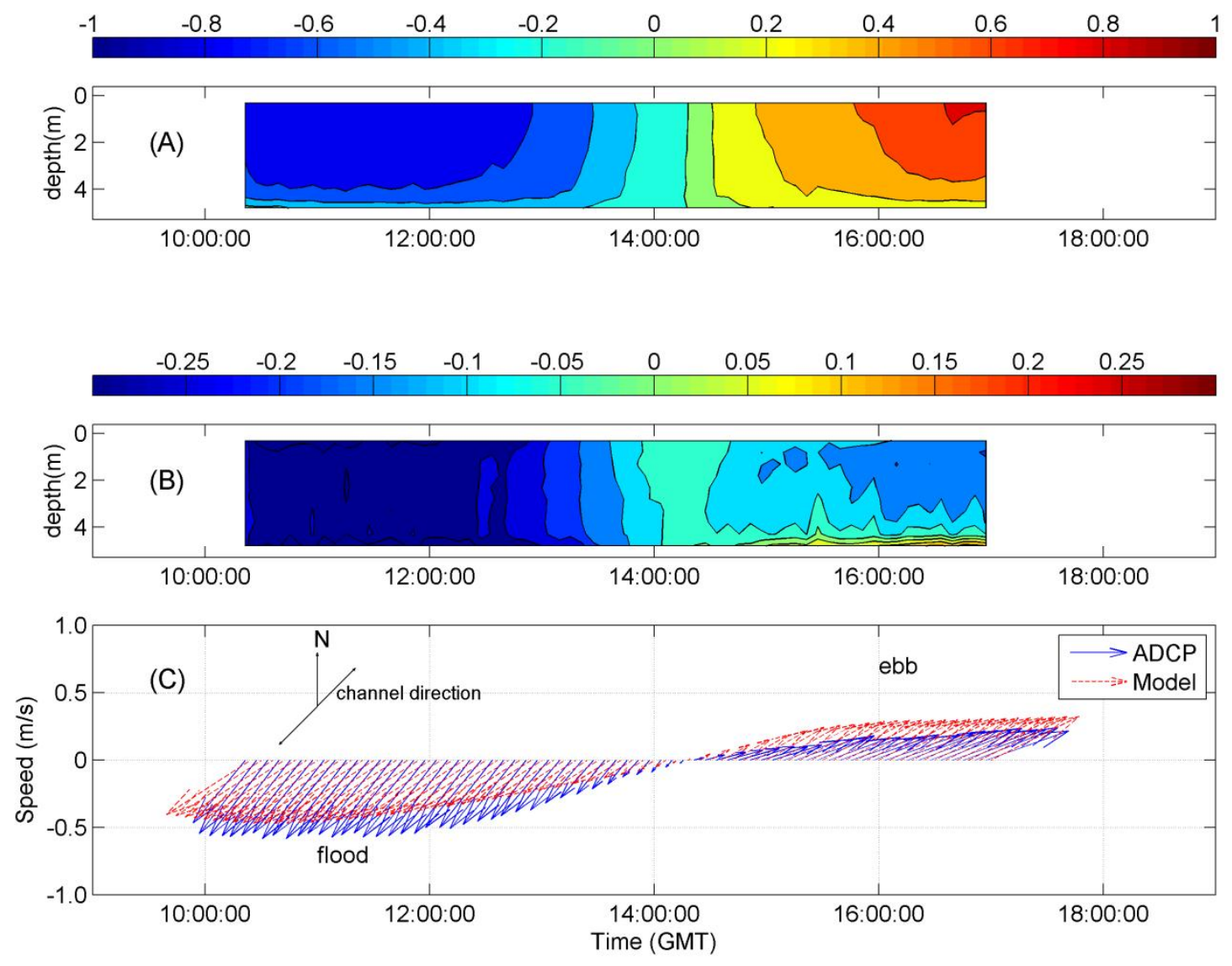

Figure 3 (A) ADCP-measured 6-min averaged along-channel velocity contour (color bar in $\mathrm{m} / \mathrm{s}$ ); (B) crosschannel velocity contour; and $(C)$ depth-averaged velocity vectors from the model and 6-min averaged ADCP measurements.

\subsection{Circulation patterns}

The tide-induced water circulations around the study area were shown in Figure 4 for one tidal cycle. The velocity field near the beach is fairly complicated due to the bay-shelf exchange through multiple inlet channels and complex geometry of the island. For Hobie Beach, Bear Cut is the most important pathway for bay water exchange with ocean water because of its vicinity to the site. Shelf water can also enter the bay through other inlet channels, such as Norris Cut that is just north of the Virginia Key and those to the south of Key Biscayne. The flow velocities in the inlet channels are several times to one order of magnitude larger than those near the beach. Both low and high tides are slack tides, when beach water is nearly stagnant with current velocity less than $0.1 \mathrm{~m} / \mathrm{s}$ (Figure 4-A and -C). The other important feature is the formation of eddies in the inlet channel and on top of flood tidal shoal. During mid-tide flooding, currents flow onto the beach from both the east and north, and converge in the middle part of the beach and then to the offshore of the beach (Figure 4-B). Adjacent to the beach, currents are mainly alongshore and northwestward. The maximum inflow can reach to 1.0 $\mathrm{m} / \mathrm{s}$ in Bear Cut. When ebbing, bay waters flow toward the beach from southwest, and then diverge around both corners of the beach (Figure 4-D). Circulation patterns may have important implications on bacteria transport and dispersion. The effectiveness of hydrodynamics on pollutant mitigation largely depends on the location of source effluent, tidal range and stage. The details will be analyzed and discussed in next section. 

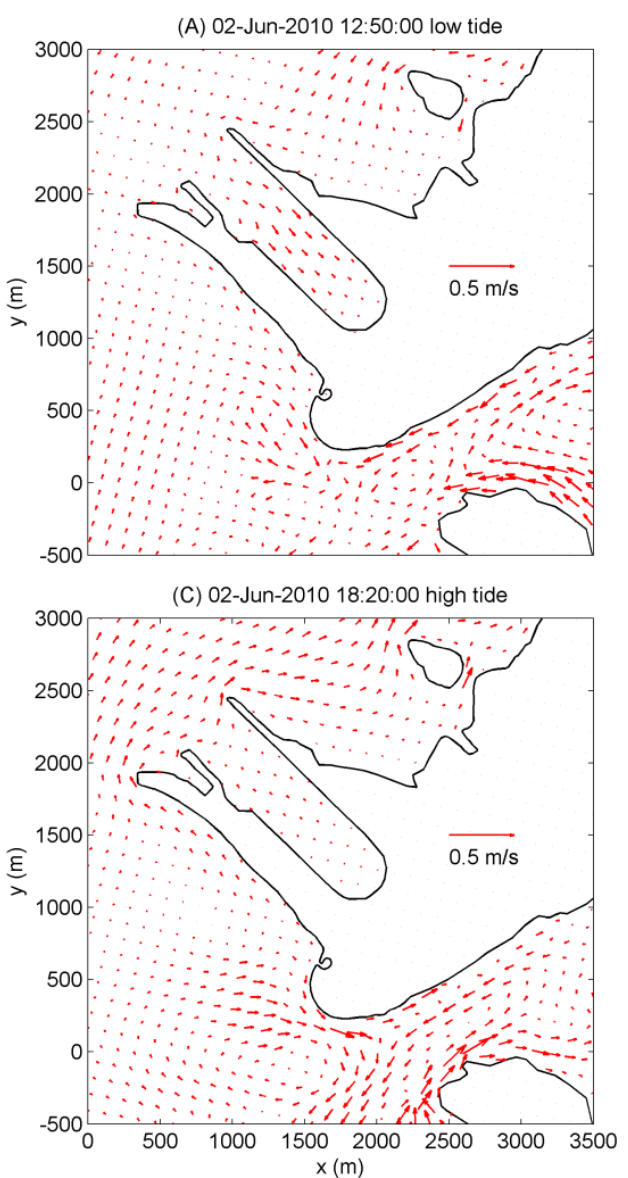

(B) 02-Jun-2010 15:50:00 mid-tide flooding

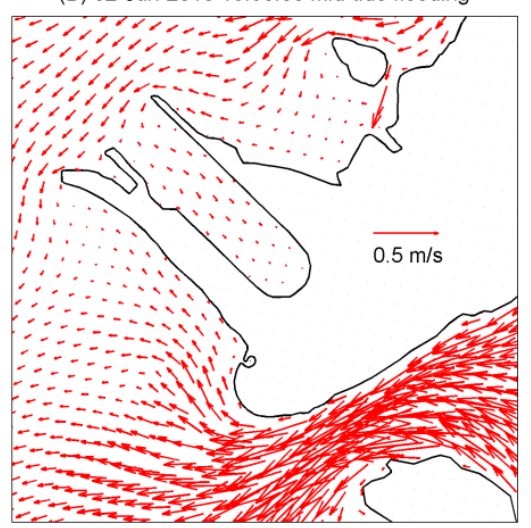

(D) 02-Jun-2010 21:20:00 mid-tide ebbing

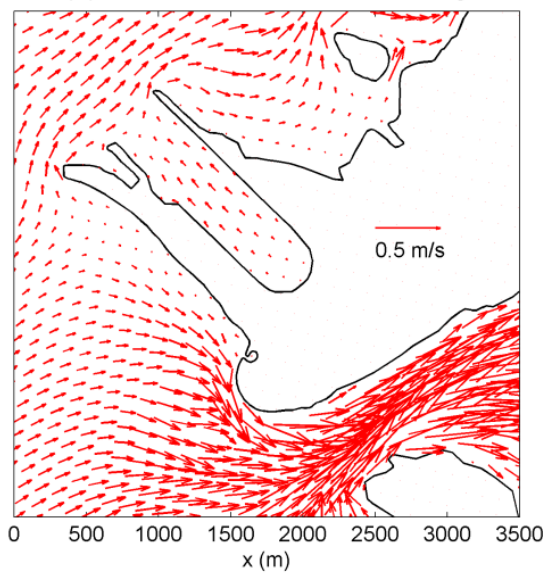

Figure 4 Snapshots of velocity field in one tidal cycle for different tidal stages: (A) low tide; (B) mid-tide flooding; (C) high tide; and (D) mid-tide ebbing.

\subsection{Scenario experiments}

\subsubsection{Dog feces}

We evaluated the impact of one big dog fecal event occurred in the middle part of the beach. The load was initially released at low tidal stage, two hours before the lowest tide, and continuous and constant release was ceased after an hour. The enterococci level could reach to hundreds of CFU/100 $\mathrm{mL}$ minutes after initial release; however, the area of impact was limited around the release point. One hour after initial release, impacted area extended hundreds of meters in both alongshore and offshore directions, but maximum level of enterococci was reduced to about $100 \mathrm{CFU} / 100 \mathrm{~mL}$ (Figure 5-A). Three hours later, the plume area was further enlarged while the enterococci levels continued decreasing (Figure 5-B). Six hours after initial release, the plume was transported by the flooding tidal current further alongshore to the northwest. Nevertheless, enterococci level at that moment became minimal, no larger than $1 \mathrm{CFU} / 100 \mathrm{~mL}$ (Figure 5-C). After one tidal cycle, enterococci no longer existed in the water (Figure 5-D). It seems that diffusion dominates initial release stage; after that, tidal current plays more important role in shaping the plume.

Next, we simulated a scenario without sunlight inactivation by setting the decay coefficient zero (Figure 5-E and -F). Although the shape of pollutant plume had more or less similar patterns at identical time, the levels of enterococci were at least one order of magnitude higher. Without inactivation, bacteria remain viable and culturable, resulting in much longer period and larger area of impact. Since dog visitation only occurs during daytime at this beach, inactivation case is more representative. It should be noted here that we keep sunlight inactivation in all later simulations. 
(A) 1 hour after initial release
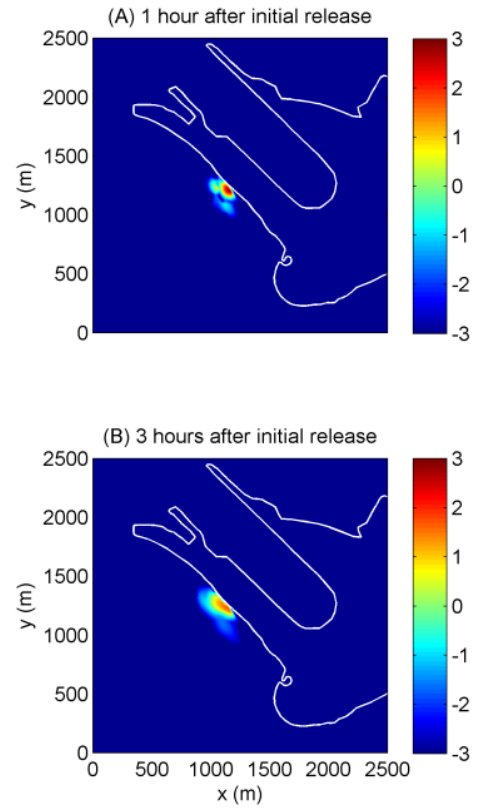

(C) 6 hours after initial release
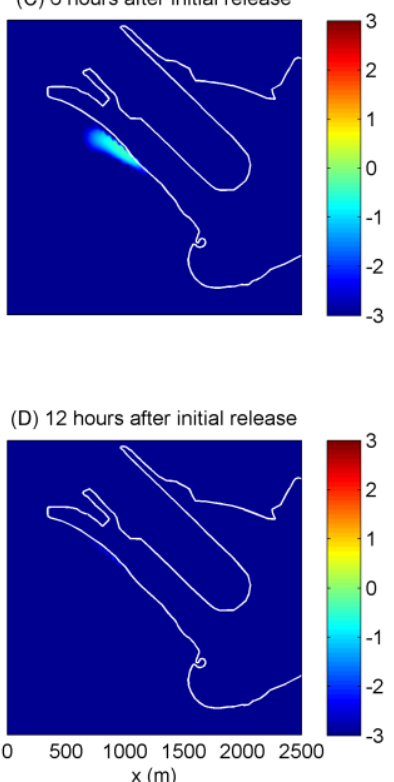
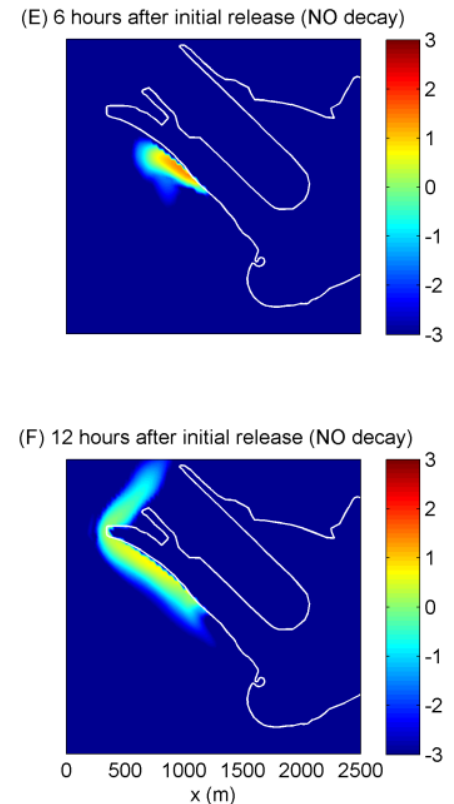

Figure $5 \log _{10}$-transformed enterococci levels under the scenario of one dog fecal event; color bar is in the unit of $\log _{10}(\mathrm{CFU} / 100 \mathrm{~mL}$ ). (A) 1 hour after initial release; (B) 3 hours after initial release; (C) 6 hours after initial release; (D) 12 hours after initial release; (E) 6 hours after initial release without inactivation; and (F) 12 hours after initial release without inactivation

\subsubsection{Sand}

Sand loading simulation treating the whole shoreline sands as sources showed that enterococci levels next to the waterline dramatically increased to near a hundred CFU/100 mL in an hour (Figure 6A), then decreased to $10 \mathrm{CFU} / 100 \mathrm{~mL}$ or less three hours later (Figure 6-B). However, enterococci could impact beyond the beach, showing the plume turned around both ends following the shoreline. The levels continued decreasing to $5 \mathrm{CFU} / 100 \mathrm{~mL}$ or less about six hours later (Figure 6-C). Twelve hours later, the beach water had very minimal enterococci left (Figure 6-D). Longshore variability is another important phenomenon, showing higher concentrations at the southeastern half than northwest half. This is mainly due to shallower water, milder slope and weaker water circulation at the southeastern part. Previous studies indicated that sand provides a protected environment for fecal bacteria, which may even regrow under favorable conditions (Yamahara et al., 2009; Piggot et al., 2012). Therefore, sand source is likely to produce persistent patterns of elevated microbial levels because certain physical processes are capable of releasing sediment-bounded microbes, such as waveinduced sediment resuspension and tidal washing (Feng et al., 2012; Ge et al., 2012). 
(A) 1 hour after initial release

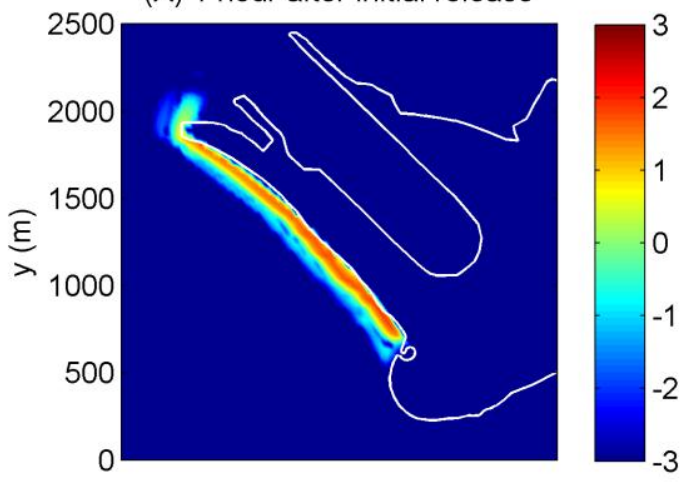

(B) 3 hours after initial release

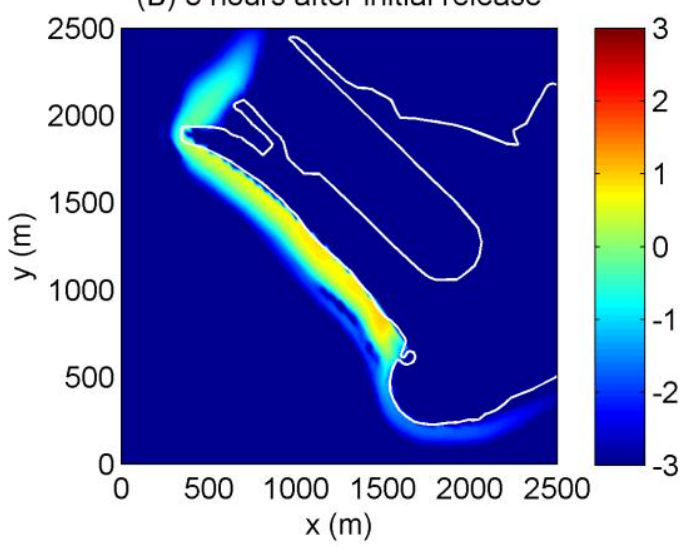

(C) 6 hours after initial release

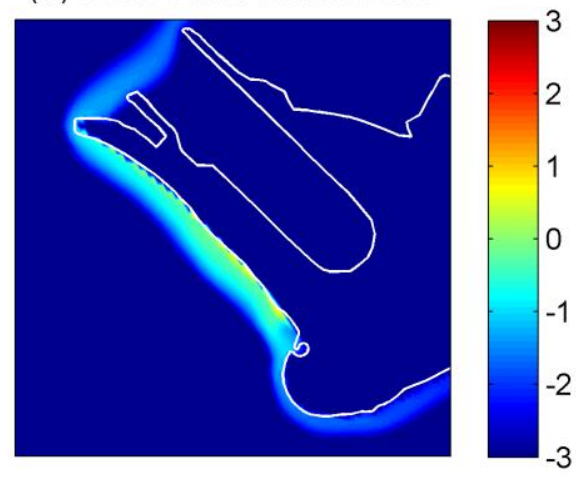

(D) 12 hours after initial release

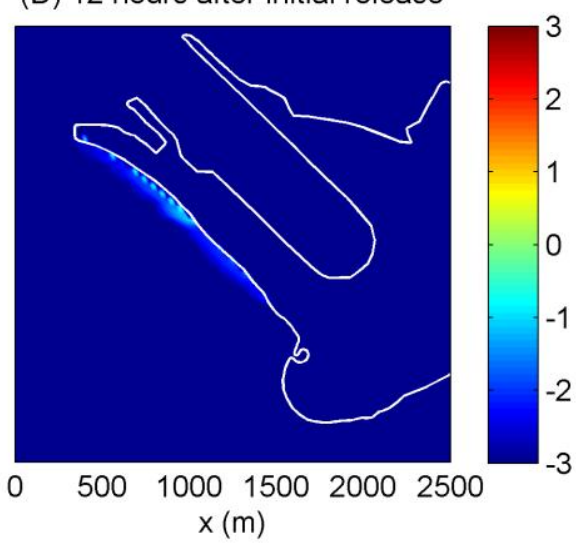

Figure 6 Log $_{10}$-transformed enterococci levels under sand loading scenario; color bar is in unit of $\log _{10}(\mathrm{CFU} / 100 \mathrm{~mL}$ ). (A) 1 hour after initial release; (B) 3 hours after initial release; (C) 6 hours after initial release; and (D) 12 hours after initial release

\subsubsection{Rainfall-runoff}

The runoff-associated enterococci entered into the water through eight spaced ditches at constant loading rate for a period of one hour. In the initial loading stage, eight plumes were discharged around corresponding runnel entrances and diffused to neighboring areas (Figure 7-A). Then, the plume was mainly stretched alongshore by tidal flow, and part of it turned around northwest tip of the island (Figure 7-B). Enterococci levels further decreased with time and the plume centers where levels are higher than the surrounding were gradually mixed up and disappeared (Figure 7-C). Very few enterococci existed in the water after twelve hours (Figure 7-D). This simulation suggested that heavy rain could be problematic in terms of water quality issues. From beach management point of view, swimmers should avoid time periods during and immediately after rains and water areas adjacent to the runnels. One thing should be points out is that the weather is most likely cloudy and overcast during rainfall events, which will suppress solar radiation and significantly reduce inactivation rate. In this case, the bacteria would be expected to stay viable for much longer and bacterial levels become even higher. 
(A) 1 hour after initial release

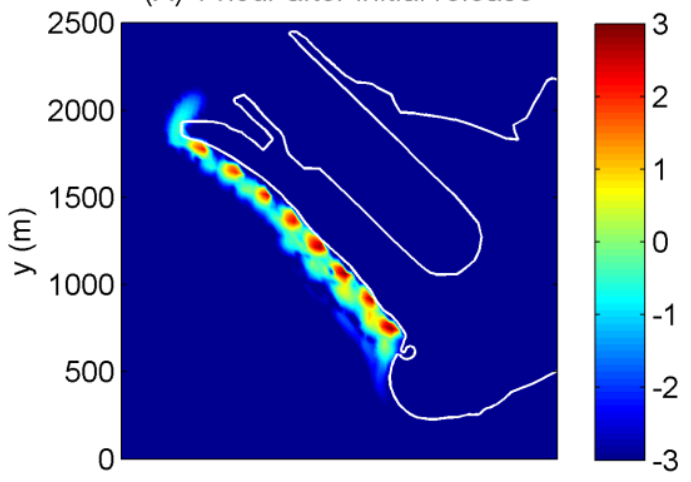

(B) 3 hours after initial release

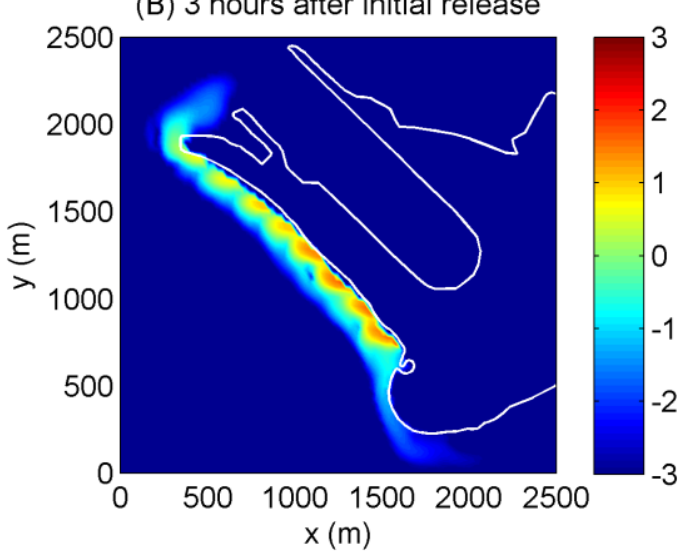

(C) 6 hours after initial release

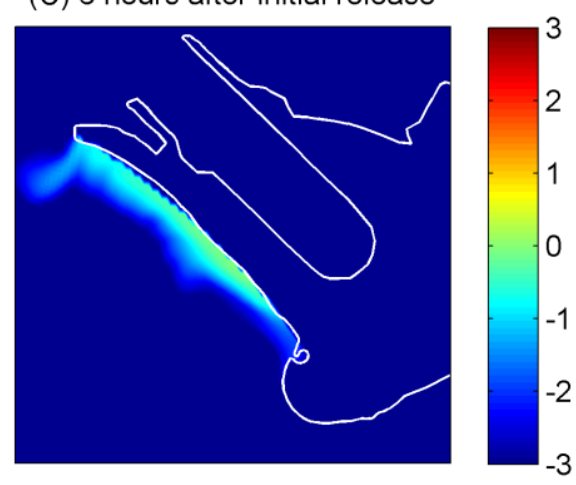

(D) 12 hours after initial release

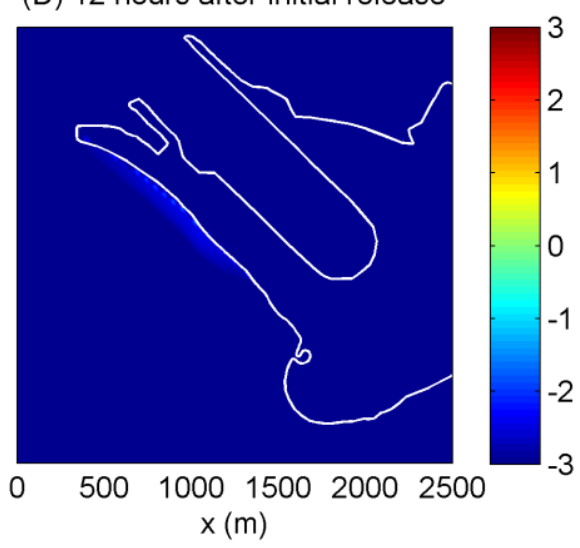

Figure 7 Log $_{10}$-transformed enterococci levels under rainfall-runoff loading scenario; color bar is in unit of $\log _{10}($ CFU/100 mL). (A) 1 hour after initial release; (B) 3 hours after initial release; (C) 6 hours after initial release; and (D) 12 hours after initial release

\subsubsection{Human}

The enterococci levels under a scenario of very high bather populations in the summer weekends were never above $10 \mathrm{CFU} / 100 \mathrm{~mL}$ in the simulation. This suggested that influence of human shedding is minimal with regard to enterococci because loading rate of bathing shedding is two to three orders of magnitude lower from than those of other three types of non-point sources (Table 1). However, we were particularly interested in $S$. aureus into the water from bathers since they are the only sources of these skin colonizing organisms in present study. During the first hour of releasing, the plume containing $S$. aureus surrounded the source grid points (Figure 8-A). With the release going on, the plume kept expanding, and the levels were also slightly increased (Figure 8-B). The flooding alongshore tidal current gradually reshaped the plume, appearing wider, longer, and leaned to the northwest; in the meantime, it also reduced $S$. aureus levels although the release continued till eight hours (Figure 8-C). After one tidal cycle, S. aureus reached a low level, less than 2 CFU/100 mL (Figure 8-D). It seems that $S$. aureus could live in the water longer than enterococci due to their smaller decay rate. Simulated levels were in the same order as prior field observations at Hobie Beach, which were tens of CFU/100 $\mathrm{mL}$ in response to high bathing loads in a June weekend (Enns et al., 2012). 
(A) 1 hour after initial release

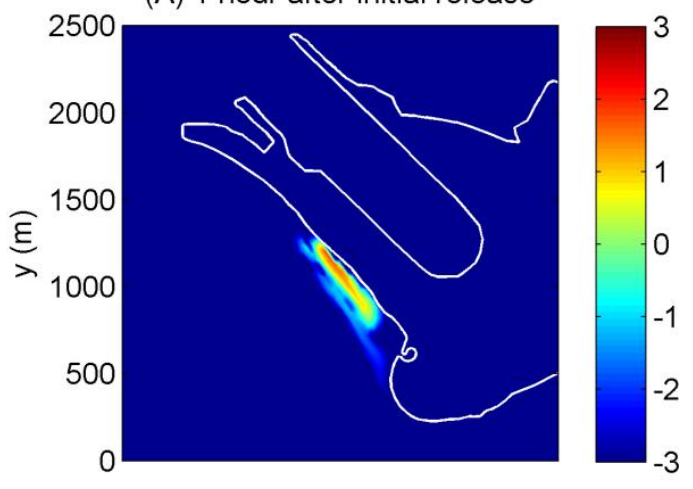

(B) 3 hours after initial release

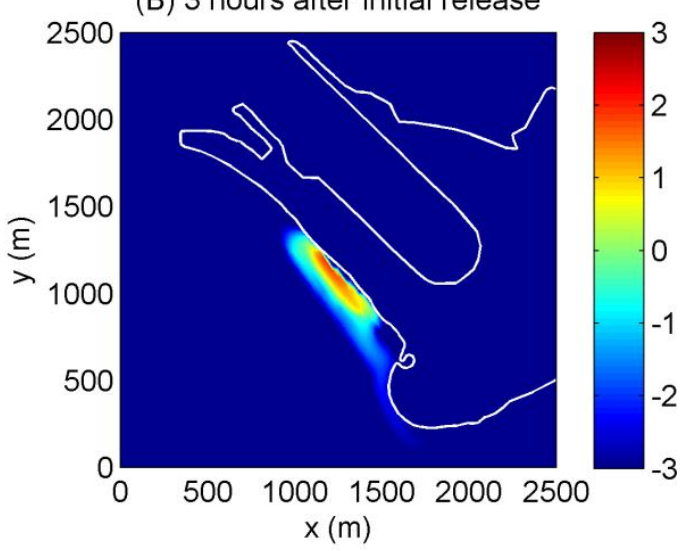

(C) 6 hours after initial release

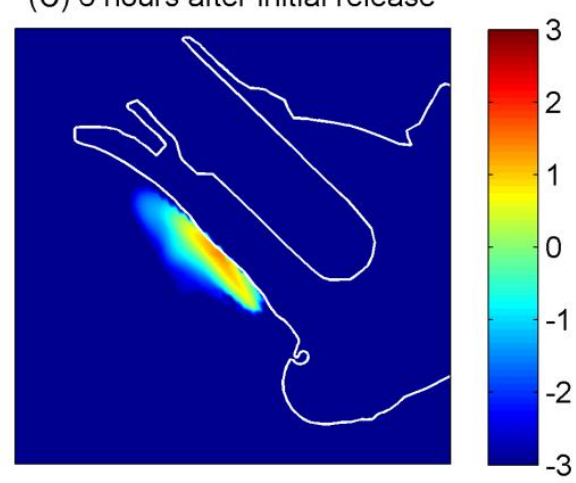

(D) 12 hours after initial release

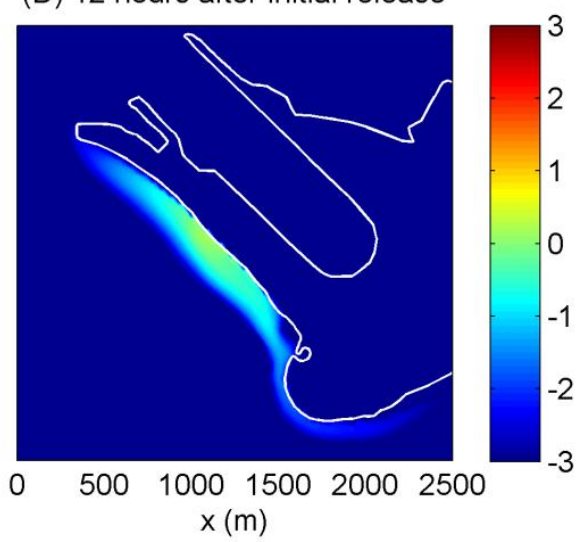

Figure $8 \log _{10}$-transformed Staphylococcus aureus levels under bather loading scenario; color bar is in unit of $\log _{10}$ (CFU/100 mL). (A) 1 hour after initial release; (B) 3 hours after initial release; (C) 6 hours after initial release; and (D) 12 hours after initial release

\section{Conclusions}

With application of Delft3D, this study established a circulation model for a coastal embayment and beach, which was capable of reproducing hydrodynamics in the study area. Numerical experiments were conducted to model far-field water quality of two types of microbes (e.g., enterococci and $S$. aureus) which may originate from four different types of non-point sources (e.g., dog feces, sand, runoff and human) under ideal "worse case" scenarios. Dog fecal event can yield spotty spikes of enterococci levels. Sand may function as pervasive and persistent enterococci source. Runoff may also produce high enterococci levels when heavy rains wash upper beach face and rainwater is drained through runnels. Bather shedding is an unimportant enterococci source but may produce S. aureus signals in beach water. Sunlight inactivation is a major daytime decay process, which can effectively reduce both enterococci and Staphylococcus aureus levels. Diffusion dominates the initial microbe release stage when high levels are formed in the shallow water next to the shoreline. Afterwards, tidal circulation plays an important role in shaping the pollutant plume and transporting microbes beyond the beach area.

This study only examined ideal cases of microbial source loading and evaluated different sources separately. In reality, the beach is influenced by a combination of those sources under a variety of physical and biological processes. For example, to correctly calculate instantaneous microbial influx from the sand, it requires the model to have capability to resolve both wave and flow forcing to suspend, deposit and transport sediment. For microbial processes, a solar-radiation-dependent decay rate is better and more representative than a constant decay rate (Sinton et al., 2002). Due to grid size restriction, another important process not resolving by present model setting is the intermittent wetting and drying of the relatively narrow intertidal zone $(\sim 10 \mathrm{~m})$, which significantly controls the cross-shore 
distribution of source abundance (Feng et al., 2012). Future work will use our recently developed microbe-hydrodynamic-morphological coupled model to resolve above issues (Feng et al., 2012). Present development of bay-scale model will provide necessary boundary conditions for future beachscale modeling efforts.

\section{ACKNOWLEDGMENTS}

This study is funded by the NSF-NIEHS Oceans and Human Health Program (NIEHS \# P50 ES12736 and NSF \#OCE0432368/0911373/1127813) and partly supported by the NSF REU program in Oceans and Human Health. We thank Naval Postgraduate School students for field support of ADCP deployment. We are grateful to Dr. John Wang and Dr. Lora Fleming for their valuable discussions and suggestions. Additional thanks are given to Deltares for providing Delft3D source codes.

\section{REFERENCES}

Elmir, S.M., 2006. Development of a Water Quality Model which Incorporates Non-point Microbial Sources. PhD dissertation, University of Miami, Coral Gables, Florida, USA, 185pp.

Elmir, S.M., Wright, M.E., Abdelzaher, A., Solo-Gabriele, H.M., Fleming, L.E., Miller, G., Rybolowik, M., Shih, M-T.P., Pillai, S.P., Cooper, J.A., and Quaye, E.A., 2007. Quantitative evaluation of bacteria released by bathers in a marine water. Water Research, 41, 3-10.

Elmir, S.M., Shibata, T., Solo-Gabriele, H.M., Sinigalliano, C.D., Gidley, M.L., Miller, G., Plano, L.R.W., Kish J., Withum, K., and Fleming, L.E., 2009. Quantitative evaluation of enterococci and Bacteroidales released by adults and toddlers in marine water. Water Research, 43, 4610-4616.

Enns, A.A., Vogel, L.J., Abdelzaher, A.M., Solo-Gabriele, H.M., Plano L.R.W., Gidley, M.L., Phillips, M.C., Klaus, J.S., Piggot, A.M, Feng, Z., Reniers A., Haus, B.K., Elmir S.M., Zhang, Y., Jimenez, N.H., Abdel-Mottaleb, N., Schoor, M.E., Brown, A., Khan, S.Q., Dameron, A.S., Salazar, N.C., and, Fleming, L.E., 2012. Spatial and temporal variation in indicator microbe sampling is Influential in beach management decisions. Water Research, doi:10.1016/j.watres.2012.01.040

Feng Z., A. Reniers, B.K. Haus, H.M. Solo-Gabriele, 2012. Modeling enterococci release, transport and inactivation at an embayed non-point source beach, Water Resources Research (in revision).

Fujioka, R.S., and T.M. Unutoa, 2006. Comparative stability and growth requirements of S. aureus and fecal indicator bacteria in seawater. Water Science \& Technology, 54(3), 169-175.

Ge Z., Whitman, R.L., Nevers, M.B., Phanikumar, S., and Byappanahalli, M.N., 2012. Nearshore hydrodynamics as loading and forcing factors for Escherichia coli contamination at an embayed beach. Limnol. Oceanogr. 57(1), 362-381.

Hsu, S.A., 1988. Coastal Meteorology. San Diego, California: Academic Press, Inc., 260pp.

Lesser, G.R., Roelvink, J.A., van Kester, J.A.T.M., and Stelling, G.S., 2004. Development and validation of a three-dimensional morphological model. Coastal Engineering, 51, 883-915.

Liu, L., Phanikumar, M.S., Molloy, S.L., Whitman, R.L., Shively, D.A., Nevers, M.B., Schwab, D.J., and Rose, J.B., 2006. Modeling the transport and inactivation of E. coli and enterococci in the near-shore region of Lake Michigan. Environmental Science \& Technology, 40 (16), 5022-5028.

MacMahan J., R. Vennell, R. Beatson, J. Brown, and A. Reniers, 2012. Divergence-free spatial velocity flow field interpolator for improving measurements from ADCP-equipped small unmanned underwater vehicle. Journal of Atmospheric and Oceanic Technology, 29, 478-484. DOI: 10.1175/JTECH-D-11-00084.1.

Pawlowicz, R., Beardsley, B., and Lentz, S., 2002. Classical tidal harmonic analysis including error estimates in MATLAB using T_TIDE. Computers \& Geosciences, 28, 929-937.

Peng, G., C. Moore, and H.C. Graber, 1999. Coastal winds in south Florida, Journal of Applied Meteorology, 38, 1740-1757.

Piggot, A.M., Klaus, J.S., Johnson, S., Philips, M., and Solo-Gabriel, H.M., 2012. Relationship between enterococci levels and sediment biofilms at recreational beaches in south Florida, Applied and Environmental Microbiology, 78(17):5973-5982. DOI: 10.1128/AEM.00603-12.

Plano, L.R., Garza, A.C., Shibata, T., Elmir, S.M., Kish, J., Sinigalliano, C.D., Gidley, M.L., Miller, G., Withum, K., Fleming, L.E., Solo-Gabriele, H.M., 2011. Shedding of Staphylococcus aureus and methicillin-resistant Staphylococcus aureus from adult and pediatric bathers in marine waters. BMC Microbiology, 11(5): 1-10.

Sanders, B.F., Arega, F., and Sutula, M., 2005. Modeling the dry-weather tidal cycle of fecal indicator bacteria in surface waters of an intertidal wetland. Water Research, 39, 3394-3408. 
Shah, A.H., Abdelzher, A.M., Phillips, M., Hernandez, R., Solo-Gabriele, H.M., Kish, J., Scorzetti, G., Fell, J.W., Diaz, M.R., Scott, T.M., Lukasik, J., Harwood, V.J., McQuaig, S., Sinigalliano, C.D., Gidley, M.L., Wanless, D., Ager, A., Lui, J., Stewart, J.R., Plano, L.R.W., and Fleming, L.E., 2011. Indicator microbes correlate with pathogenic bacteria, yeasts and helminthes in sand at a subtropical recreational beach site. Journal of Applied Microbiology, 110(6), 1571-1583.

Shibata, T., Solo-Gabriele, H.M., Fleming, L.E., and Elmir, S., 2004. Monitoring marine recreational water quality using multiple microbial indicators in an urban tropical environment. Water Research, 38, 3119-3131.

Sinton, L.W., Hall, C.H., Lynch, P.A., and Davies-Colley, R.J., 2002. Sunlight inactivation of fecal indicator bacteria and bacteriophages from waste stabilization pond effluent in fresh and saline waters. Applied and Environmental Microbiology, 68 (3), 1122-1131.

Shuval H., 2003. Estimating the global burden of thalassogenic diseases: human infectious diseases caused by wastewater pollution of the marine environment. Journal of Water and Health, 2, 53-64.

USEPA, 1986. Ambient water quality criteria for bacteria. EPA 440/5-84-002. Washington D.C.

Wang, J.D, Luo, J., and Ault.J.S. 2003. Flows, salinity, and some implications for larval transport in south Biscayne Bay, Florida. Bulletin of Marine Science, 72, 695-723.

Wang, J.D., Solo-Gabriele, H.M., Abdelzaher, A.M., and Fleming, L.E., 2010. Estimation of enterococci input from bathers and animals on a recreational beach using camera images. Marine Pollution Bulletin, 60, 1270-1278.

Wright, M.E., Solo-Gabriele, H.M., Elmir, S., and Fleming, L.E., 2009. Microbial load from animal feces at a recreational beach. Marine Pollution Bulletin, 58, 1649-1656.

Wright, M.E., Abdelzaher, A.M., Solo-Gabriele, H.M., Elmir, S., and Fleming, L.E., 2011. The intertidal zone is the pathway of input of enterococci to a subtropical recreational marine beach. Water Science \& Technology, 63.3, 542-549.

Yamahara K.M., Walters, S.P., and Boehm, A.B., 2009. Growth of enterococci in unaltered, unseeded beach sands subjected to tidal wetting. Applied and Environmental Microbiology, 75 (6), $1517-$ 1524.

Zhu, X., Wang, J.D., Solo-Gabriele, H.M., and Fleming, L.E., 2011. A water quality modeling study of non-point sources at recreational marine beaches. Water Research, 45, 2985-2995. 